\title{
Distribusi zakat di Indonesia: antara sentralisasi dan desentralisasi
}

\author{
Aden Rosadi dan Mohamad Anton Athoillah \\ Fakultas Syariah dan Hukum UIN Sunan Gunung Jati Bandung \\ E-mail:adenrosadi@yahoo.com dankafabil@yahoo.com \\ DOI: 10.18326/ijtihad.v15i2.237-256
}

The problem of poverty that be falls in the muslim communities is influenced by the systems used in the distribution of zakah funds. Each system used has some advantages and disadvantages in accordance with the priority issues to be resolved. If the priority is to reduce poverty, then decentralization is the best choice of either of these options. This paper would like to reiterate the importance of decentralized distribution of charity funds so that funds raised by an area will be returned to the area and the problems of poverty faced from which the funds collected will soon be resolved.

Masalah kemiskinan yang mendera masyarakat muslim dipengaruhi di antaranya oleh sistem yang digunakan dalam distribusi dana zakat. Masing-masing sistem yang digunakan memiliki kelebihan dan kekurangan sesuai dengan prioritas masalah yang hendak diselesaikan. Jika prioritasnya adalah untuk mengentaskan kemiskinan, maka desentralisasi adalah pilihan terbaik dari setiap pilihan yang ada. Tulisan ini ingin menegaskan kembali pentingnya desentralisasi distribusi dana zakat sehingga dana yang dihimpun oleh suatu daerah akan dikembalikan kepada daerah itu, dan masalah kemiskinan yang dihadapi dari mana dana itu dihimpun akan segera dapat diselesaikan.

Keywords: Zakab; Decentralization; Poverty; Distributive justice

\section{Pendahuluan}

Kemiskinan merupakan masalah utama kemanusiaan. Setiap agama di dunia memeranginya dengan segala instrument yang dimilikinya. Islam memeranginya, di antaranya dengan kewajiban untuk menunaikan zakat yang didistribusikan kepada orang-orang miskin. Bahkan dikatakan sebagai pendusta agama, jika seseorang mengaku mukmin tetapi tidak membantu untuk menyantuni orang-orang miskin (Qs. al-Ma'un/107:3). 
Keterlibatan banyak pihak, baik negara ataupun swasta, tidak dapat diabaikan dalam upaya untuk mengentaskan kemiskinan. Banyak dana telah dikeluarkan untuk mendukung kerja lembaga swadaya masyarakat dalam meningkatkan produktivitas masyarakat lemah di berbagai sektor kehidupan, tetapi sering sekali kemampuan produktif masyarakat tersebut tidak berarti banyak bagi peningkatan kesejahteraan mereka akibat berbagai kebijakan yang tidak memihak kepada kepentingan masyarakat (Mas'udi, 2010:58-59).

Masalah yang menjadi penyebab lahirnya kemiskinan sangatlah rumit. Kemiskinan tidak hanya disebabkan karena kurangnya pendapatan, tetapi juga berkaitan dengan kekurangan lahan yang sempit, kondisi geografis, tingkat pendidikan, serta sikap mental yang saling berkaitan satu dengan yang lain (Kasim, 2006:31). Berarti ada tiga faktor yang berperan langsung sebagai penyebab terjadinya kemiskinan, yaitu faktor alamiah, faktor struktural, dan faktor yang berada di dalam diri orang miskin itu sendiri (Rejekiningsih, 2011:35). Banyaknya faktor yang menjadi penyebab lahirnya kemiskinan, semuanya harus disentuh dan diselesaikan.

Upaya yang dapat dilakukan untuk menyentuh dan menyelesaikan faktor-faktor penyebab kemiskinan di atas adalah melalui distribusi dana zakat secara adil dan menyeluruh. Distribusi ini tidak dapat dilakukan secara personal dan tanpa rencana, kecuali melalui kelembagaan dan perencanaan yang sesuai sehingga tujuan adanya distribusi dana zakat ini tercapai. Berbagai upaya telah dilakukan, baik oleh negara ataupun organisasi masyarakat dan lembaga swadaya masyarakat, untuk dapat mendistribusikan dana zakat secara sesuai dan tepat sasaran.

Hilman Latief (2010) telah menggagas praktik filantropi antara sentralisasi, desentralisasi, dan atomisasi. Kasus yang diangkat dalam buku ini adalah dana zakat yang dihimpun oleh Muhammadiyah dan didistribusikan berdasarkan praktik pendistribusian tertentu kepada para mustahik, baik pada tingkat pimpinan wilayah, daerah, cabang, dan ranting Muhammadiyah. Beberapa tingkat pimpinan wilayah dan daerah Muhammadiyah menerapkan desentralisasi dan beberapa tingkat daerah, cabang dan ranting lainnya menerapkan "otonomisasi penuh" atau atomisasi. Dalam buku ini juga didiskusikan praktik sentralisasi pada administrasi tetapi desentralisasi pada pengelolaan.

Gagasan lain disampaikan oleh Masdar Farid Mas'udi (2010). Gagasan ini menyinggung pentingnya desentralisasi dalam pengelolaan dana zakat. Dengan prinsip desentralisasi ini (h. 116), akan dihindari suatu ironi, yakni suatu daerah dikuras besar-besaran pajak (zakat)-nya 


\section{Distribusi zakat di Indonesia: ...(Aden Rosadi dan Mohamad Anton Athoillah)}

oleh pemerintah pusat sementara rakyat miskin di daerah itu sendiri justeru dibiarkan sengsara dalam kemiskinannya.

Berdasarkan uraian di atas, tulisan ini bermaksud untuk menegaskan kembali pentingnya sistem desentralisasi pada pengelolaan dan pendistribusian dana zakat. Upaya ini dilakukan sebagai upaya untuk mendapatkan cara yang terbaik dalam pengelolaan dan pendistribusian zakat sehingga tujuan disyari'atkannya zakat sebagai upaya untuk mengentaskan kemiskinan dapat segera dicapai.

\section{Perintah zakat dalam Islam}

Dalam Islam, ketentuan zakat ditegaskan tidak hanya berdasarkan al-Qur'an tetapi juga hadis. Kata zakat dalam al-Qur'an disebutkan sebanyak 32 kali ('Abd al-Baqy, $1364 \mathrm{H}$ ). Sedangkan dalam hadis ditemukan jauh lebih banyak jumlahnya (Wensinck, 1936) daripada dalam al-Qur'an. Berbagai istilah pun diperkenalkan oleh al-Qur'an, yang istilah itu sering ditafsirkan dengan zakat. Zakat disebut infak (Qs. al-Taubah/9:34) karena hakikatnya zakat itu adalah penyerahan harta untuk kebajikan-kebajikan yang diperintahkan Allah Swt. Zakat disebut sedekah (Qs. al-Taubah/9:60 dan 103) karena memang salah satu tujuan utama zakat adalah untuk mendekatkan diri kepada Allah Swt. Zakat disebut hak, oleh karena memang zakat itu merupakan ketetapan yang bersifat pasti dari Allah Swt yang harus diberikan kepada mereka yang berhak (Hafidhuddin, 2002:9).

Zakat adalah pillar agama Islam ketiga setelah salat. Jika salat dipahami sebagai ibadah badaniyah, maka zakat dipahami sebagai ibadah maliyah (Ibn Manshur, 2008:46), bahkan dikatakan sebagai ibadah maliyah al-ijtima'iyyah, yaitu ibadah di bidang harta yang memiliki fungsi strategis, penting, dan menentukan dalam membangun kesejahteraan masyarakat (Hafidhuddin, 2002:15). Karena zakat adalah ibadah maliyah, maka zakat dalam Islam dapat dilihat dari dua aspek, yaitu dari aspek agama dan aspek ekonomi. Dari aspek agama, zakat adalah ibadah yang diperintahkan oleh Allah Swt dan sebagai bukti ketaatan seseorang kepada perintah Allah Swt. Dari aspek ekonomi, zakat memiliki dampak positif, baik pada tingkat ekonomi mikro ataupun ekonomi makro. Pada tingkat ekonomi mikro, zakat memiliki implikasi ekonomi terhadap perilaku konsumsi dan tabungan individu serta perilaku produksi dan investasi perusahaan tanpa berpengaruh negatif pada insentif bekerja. Pada tingkat 
ekonomi makro, zakat memiliki implikasi ekonomi terhadap efisiensi alokatif, penciptaan lapangan kerja, pertumbuhan ekonomi, stabilitas makro ekonomi, distribusi pendapatan, pengentasan kemiskinan dan jejaring pengaman sosial (Iqbal, 2011:74-75). Pada aspek sosial ekonomi, zakat memberikan dampak terciptanya keamanan masyarakat dan menghilangkan pertentangan kelas karena ketajamannya perbedaan pendapatan (Sasono, 1998:46).

Dari lima pillar agama Islam (syahadat, salat, zakat, puasa, dan haji), zakat adalah satusatunya ibadah yang bersentuhan langsung dengan kesejahteraan kehidupan masyarakat. Dari ibadah ini, terdapat beberapa tujuan syara', yaitu: (1) sebagai bentuk ketaatan kepada Allah Swt untuk menunaikan apa yang diperintahkan; (2) sebagai bentuk syukur atas nikmat yang diberikan oleh Allah Swt; (3) sebagai upaya untuk mensucikan diri dari dosa; (4) sebagai upaya menghindarkan diri dari sifat kikir; (5) sebagai upaya untuk membersihkan harta; (6) sebagai upaya menghindarkan orang-orang kafir dari sifat iri dan dengki kepada orangorang kaya; (7) melipatgandakan kebaikan orang yang menunaikannya dan menaikkan derajatnya; (8) membantu dan meningkatkan kesejahteraan orang-orang fakir; (9) menumbuh kembangkan harta zakat; (10) sebagai bentuk tanggung jawab terhadap masalah sosial; (11) menumbuh kembangkan ekonomi Islam; (12) Dakwah menuju Allah Swt (Ibn Manshur, 2008:48-56). Berangkat dari tujuan-tujuan syara' di atas, berarti zakat tidak hanya memiliki dampak kepada pribadi, tetapi berdampak kepada masyarakat. Bahkan dalam artikel yang ditulis oleh Muhammad Abdullah dan Abdul Quddus Suhaib (2011), zakat akan berdampak secara kolektif di antaranya kepada terciptanya harmoni dan keadilan sosial, keamanan sosial, persaudaraan, serta kedamaian dan kemakmuran.

\section{Distribusi pendapatan melalui mekanisme zakat}

Al-Qur'an secara tegas menyatakan bahwa manusia diciptakan untuk mewujudkan kesejahteraan di muka bumi (Qs. Hud/11:61). Konsep distribusi atau redistribusi kesejahteraan, baik dalam al-Qur'an ('Abd Al-Baqy, $1364 \mathrm{H}$ ) ataupun dalam hadis (Wensinck, 1936), sangat banyak disebutkan segara gamblang. Disejajarkannya perintah zakat dengan kewajiban utama lainnya seperti salat (seperti dalam surat al-Baqarah/2:43, 83, dan 110), menjadi bukti bahwa Islam sangat menekankan kepada para penganutnya untuk memperhatikan kondisi kesejahteraan orang lain. 


\section{Distribusi zakat di Indonesia: ...(Aden Rosadi dan Mohamad Anton Athoillah)}

Proses mewujudkan keadilan distributif pada wilayah kekayaan dan kesejahteraan, tetap menempati posisi yang sangat penting dalam ajaran Islam (Amalia, 2009). Adanya ketentuan bahwa harta itu jangan hanya beredar di kalangan orang kaya (Qs. al-Hasyr/59:7); dalam harta orang kaya itu terdapat hak fakir miskin (Qs. al-Ma'arij/70:24); kewajiban untuk tolong menolong dalam kebaikan (Qs. al-Maidah/5:2); meringankan beban orang lain yang mengalami kesulitan (Qs. al-Baqarah/2:280); dan lain-lain, telah secara tegas disebutkan dalam Qur'an. Bahkan pada masa awal kenabian pun (periode Makkah), justru aspek humanitas Islam terlihat begitu kental menyatu dengan aspek monoteisme (Qs. al-Balad/90:11-16), mendahului perintah penyusunan sistem hukum dan perundang-undangan (Quthub, 1968).

Islam merumuskan tiga keadilan distributif, yaitu: (1) pemerataan sumber daya alam dan lingkungan dalam kerangka partisipasi; (2) redistribusi kekayaan dan pendapatan dalam rangka memastikan keamanan sosial, dan meningkatkan kapasitas dan otoritas bagi mereka yang kurang mampu; (3) peran negara merupakan pelengkap bagi pasar yang etis dengan maksud untuk menjamin rasa keadilan dan tercapainya keadilan publik (Baidhawy, 2012:242). Dalam rumusan ketiga di atas, negara dianggap masih memiliki peran. Pada fase Madinah, peran ini dilakukan oleh Rasulullah Saw sebagai pemimpin negara. Peran ini kemudian dilanjutkan oleh empat khalifah Islam berikutnya, yaitu Abu Bakar (w. 13 H/ 634 H), Umar ibn Khattab (w. $23 \mathrm{H} / 644 \mathrm{M}$ ), Utsman ibn Affan, dan Ali ibn Abi Thalib.

Perbedaan kekayaan atau kesejahteraan di antara sesama manusia memang diakui oleh Islam. Hal ini bukan hanya ditegaskan dalam al-Qur'an (Qs. al-An'am/6:165) tetapi dalam hadis riwayat Muslim (1998). Dalam hadis yang diriwayatkan oleh Muslim ini, diceritakan bagaimana orang-orang miskin mengadu kepada Rasulullah Saw tentang keadaan orangorang kaya yang mampu untuk bersedekah dan memerdekakan budak sedangkan mereka (orang-orang miskin) tidak mampu untuk bersedekah dan memerdekakan budak.

Ada banyak cara yang dilakukan untuk memaksimalkan peran orang kaya dalam keterlibatannya untuk mensejahterakan orang-orang miskin. Upaya yang dilakukan tidak hanya dibatasi dengan bersedekah dan memerdekakan sebagaimana dikatakan dalam hadis di atas. Beberapa upaya lainnya yang dapat dilakukan adalah dengan bermitra usaha, menjalin hubungan perburuhan, melalui mekanisme pasar, dan melalui mekanisme zakat (Perwataatmadja dan Byarwati, 2008) atau dikembangkan sesuai dengan tingkat kerumitan masalah yang hendak diselesaikan. 
Dalam al-Qur'an, ayat yang dijadikan landasan utama fungsi redistribusi kesejahteraan melalui zakat adalah surat al-Taubah/9:60, yang justeru tidak menggunakan kata zakat tetapi sedekah. Secara literal kata ini, paling tidak, berarti “jujur" dan "benar". Hal inilah yang kemudian dapat dijadikan pandangan bahwa di antara dasar kejujuran dan kebenaran iman seseorang itu dapat diketahui dari penerimaannya terhadap ayat-ayat zakat, baik ayat 60 surat al-Taubah maupun ayat-ayat yang turun sebelumnya. Berdasarkan informasi historis al-Suyuthi $(1426 \mathrm{H})$, ayat 60 surat al-Taubah turun pada tahun ke-9 hijriyyah. Sementara itu kewajiban zakat sudah ditetapkan pada awal hijrah dan kebiasaan bersedekah sudah ada sebelum zakat diwajibkan. Hal ini juga dapat menjadi representasi simbolik amal saleh seseorang, sebagai konsekuensi atau perwujudan kejujuran dan kebenaran iman dalam dirinya. Sedangkan dalam riwayat, terdapat sejumlah riwayat yang secara eksplisit menyatakan bahwa zakat itu hak mustahik, dengan fakir miskin sebagai prioritasnya (Ridha, 1354 H; Zuhaily, 2009).

Sebagai salah satu sistem distribusi, sistem zakat adalah sistem distribusi yang telah ditentukan, baik nishab, kadar, dan terutama peruntukkannya. Merujuk kepada surat alTaubah/9:60 ada delapan golongan orang yang berhak untuk menerima zakat. Distribusi yang meluas dari sistem zakat, umumnya berangkat dari diperluasnya makna dari kedelapan golongan di atas (Khoiruddin, 2014). Bahkan karena pertimbangan tertentu, justeru sebagian golongan mustahik tidak diberikan haknya sebagai mustahik zakat, sebagaimana yang dilakukan oleh khalifah Umar kepada muallaf pada saat itu, dengan alasan karena negara Islam telah kuat (Perwataatmadja dan Byarwati, 2008:75)

Merujuk kepada hadis yang diriwayatkan oleh Bukhari (1998) bahwa zakat itu dipungut dari orang-orang kaya dan diserahkan kepada orang-orang miskin, telah memberikan gambaran dengan jelas bahwa harus ada distribusi atau bahkan redistribusi kesejahteraan di antara sesama manusia tanpa melihat latar belakang keyakinan yang dianutnya, kecuali karena kondisi ekonominya. Tidak heran, meski ada beberapa ulama yang berpendapat bahwa mereka yang berhak untuk menerima zakat adalah dari kalangan kaum muslimin saja, tetapi setelah dilakukan penelusuran bibliografis, ditemukan sejumlah pendapat yang menyatakan diperbolehkannya kalangan non-muslim untuk menerima zakat, dengan beberapa catatan tertentu (al-Qaradhawy, 1991). Sebut saja seperti Umar ibn Khattab (w. 23 H/ 644 M), 'Ikrimah (w. 105 H/ 723 M), Ibn Sirin (w. 110 H/ 728 M), al-Zuhri (w. 124 H/ 742 M), 
Zufar (w. 182 H/ 802 H), Ibn Abi Syaibah (w. 235 H/ 849 M), al-Jashshash (w. 370 H/ 981 M), dan sebagian ulama dari kalangan Syi'ah Zaidiyah. Mereka berpendapat bolehnya bagi kalangan non-muslim untuk menerima zakat (Kasani, 2003).

Dalam disertasi yang ditulis Yusuf al-Qaradhawy (1991), ayat-ayat zakat selalu dikaitkan dengan kemiskinan dan bagaimana kemiskinan itu diminimalkan. Di antara yang menarik dalam disertasinya adalah dibedakannya zakat pada periode Mekah dan periode Madinah. Meski ayat-ayat zakat banyak tersebar dalam ayat-ayat Mekah tetapi zakat itu sendiri diwajibkan di Madinah. Jika pada fase Mekah, zakat tidak ditentukan batas besarnya tetapi diserahkan kepada rasa iman, kemurahan hati, dan perasaan tanggung jawab seseorang kepada orang lain, maka di Madinah mereka merupakan kelompok yang memiliki daerah, eksistensi, dan pemerintahan sendiri sehingga lahir adanya beban tanggung jawab dalam bentuk baru tertentu.

Disertasi yang ditulis Ichsan Iqbal (2011) membuktikan bahwa fakir-miskin menempati urutan teratas sebagai mustahik penerima dana zakat. Dari data yang didapatnya dari laporan keuangan Dompet Dhuafa tahun 1428 H - 1430 Hijriyah, urutan pertama sebagai pengguna dana zakat adalah fakir-miskin, dilanjutkan dengan dana untuk bantuan kemanusiaan, dana operasional, dan pemasyarakatan ZISWAF untuk tahun 1428 H. Selengkapnya tentang penggunaan dana zakat Dompet Dhuafa ini dapat dilihat dalam tabel sebagai berikut:

Tabel 1

Data penggunaan dana dompet dhuafa Dari tahun 1428 h - 1430 H Dalam Jutaan Rupiah

\begin{tabular}{|c|c|c|c|c|}
\hline \multirow{2}{*}{ No } & \multirow{2}{*}{ Dana } & \multicolumn{3}{|c|}{ Tahun } \\
\hline & & $1428 \mathrm{H}$ & $1429 \mathrm{H}$ & $1430 \mathrm{H}$ \\
\hline 01 & Takir-Miskin & 17.260 & 17.484 & 20.142 \\
\hline 02 & Gharimin & 98 & 2 & 14 \\
\hline 03 & Ibnu Sabil & 7 & 16 & 0 \\
\hline 04 & Hi Saljilillah & 2.106 & 6.933 & 8.491 \\
\hline 05 & Muallaf & 6 & 3 & 6 \\
\hline 06 & Kegiatan Sosial dan Pondiclikann & 1.770 & 3.956 & 1.973 \\
\hline 07 & Pemasyarakatan ZISW $\Lambda F$ & 4.635 & 6.880 & 5.880 \\
\hline 08 & Uang Muka Kegiatan & 1.172 & 1.261 & 176 \\
\hline 09 & Bantuan Kemanusiaan & 9.202 & 1.924 & 4.128 \\
\hline 10 & Dana Operasional & 5.112 & 5.852 & 8.726 \\
\hline & Jumlati & 41.374 & 44.311 & 49.536 \\
\hline
\end{tabular}

Sumber: Laporan Keuangan Dompet Dhuafa dalam Ichsan Iqbal (2011:140). 
Tabel di atas membuktikan upaya yang dilakukan oleh lembaga zakat untuk terlibat aktif menuntaskan kemiskinan. Dari data di atas dapat disimpulkan 42\% untuk tahun $1428 \mathrm{H}$; 39\% untuk tahun $1429 \mathrm{H}$; 41\% untuk tahun $1430 \mathrm{H}$, dari dana yang didapat didistribusikan kepada fakir-miskin.

\section{Pro-kontra sentralisasi distribusi zakat}

Baik sentralisasi ataupun desentralisasi pernah dilakukan oleh Rasulullah Saw pada masa kepemimpinannya. Rasulullah Saw pernah mengirim Ala al-Hadrami ke Bahrain dan Amr ke Oman pada tahun 8 Hijriyah dan Muadz ke Yaman pada tahun 9 Hijriyah. Beberapa riwayat menegaskan bahwa zakat dari satu daerah disalurkan ke daerah itu juga, tidak dibawa ke Madinah, tetapi beberapa riwayat mengisahkan sebagian zakat ada juga yang dikirim ke Madinah (Karim, 2001:192).

Dalam perjalanan sejarah, sentralisasi zakat pernah dilakukan juga oleh khalifah Abu Bakar (w. $13 \mathrm{H} / 634 \mathrm{H}$ ). Perilaku ini dilakukan di antaranya karena adanya kondisi tertentu (seperti untuk memobilisasi dana perang melawan Persia dan Bizantium) yang mengharuskan dana zakat untuk disentralisasikan. Kebijakan ini yang pada awalnya dipandang lebih bersifat politis (Vaglieri, 2008) daripada normatif ini, telah berkembang ke arah teologis (Na'im, 2008).

Pada masa khalifah Abu Bakar, zakat sebagai salah satu sumber pendapatan negara ditangani penghimpunan dan pendistribusiannya oleh negara. Orang yang dianggap wajib zakat, dipaksa untuk mengeluarkan zakat. Bahkan orang yang enggan mengeluarkan zakat diperangi dengan keras oleh khalifah (Mas'udi, 2010). Sejumlah orang yang dipandang masuk dalam kategori orang yang berkewajiban mengeluarkan zakat, tetapi tidak mau menyerahkan zakatnya kepada para petugas pengumpul zakat untuk diserahkan ke Madinah, sebagai pusat pemerintahan, telah dimasukkan ke dalam kelompok orang-orang yang murtad. Keputusan khalifah Abu Bakar (w. 13 H/ 634 M) memerangi mereka, menjadi satu paket bersamasama dengan keputusan untuk memerangi orang yang secara terang-terangan keluar dari Islam dan (kelompok) orang yang mengaku menjadi nabi setelah wafatnya Nabi Muhammad SAW (Hitti, 1946).

Ada tiga alasan yang dapat dikemukakan kenapa Abu Bakar tetap memerangi orangorang yang enggan untuk mengeluarkan zakat: (1) zakat merupakan hak harta yang harus 


\section{Distribusi zakat di Indonesia: ...(Aden Rosadi dan Mohamad Anton Athoillah)}

diambil dari orang kaya dan diberikan kepada orang miskin; (2) ada kemungkinan sikap mereka untuk tetap melakukan shalat dengan tujuan membimbangkan kaum muslimin dalam mengambil tindakan tegas terhadap mereka karena secara lahiriah mereka tampak sebagai muslim; (3) zakat sudah menjadi syi'ar Islam (Ahmad, 2011:197). Sikap Abu Bakar yang asalnya ditentang oleh Umar ibn Khattab (w. 23 H/ 664 M) tetapi kemudian beliau menyetujuinya ini (Bukhari, 1998), jika dianalisis lebih lanjut, tentu saja "delik hukum"-nya menjadi berbeda. Setelah khalifah kedua ini menggantikan kedudukan Abu Bakar sebagai khalifah pertama, khalifah Umar ibn Khattab segera membebaskan seluruh tawanan harb al-Riddah yang “delik hukum”-nya berupa penolakan pembayaran zakat. Mereka yang menolak pembayaran zakat itu tidak dapat dipandang telah keluar dari Islam, karena mereka tetap melaksanakan salat (Suyuthi, 2003). Dalam analisis Haekal, mereka menuntut otonomi pemerintahan sebagaimana kebijakan pemerintahan Nabi ketika beliau masih hidup dan sekaligus menuntut desentralisasi pendistribusian dana zakat (Na'im, 2008).

Ada beberapa alasan yang dapat dikemukakan kenapa mereka enggan untuk mengeluarkan zakat. Mereka yang enggan untuk mengeluarkan zakat beralasan dengan merujuk kepada surat al-Taubah/9:103. Menurut pandangan mereka bahwa mukhatab dalam ayat di atas adalah Rasulullah Saw dan do'a yang menenteramkan mereka adalah Rasulullah. Mereka enggan membayar zakat kecuali kepada orang yang do'anya menjadi ketenteraman jiwa mereka (Ahmad, 2011:96). Alasan lain dikemukakan dalam buku Tarikh al-Rasul wa alMuluk, sebagian mereka menolak untuk membayar kepada pemerintah pusat karena telah membayar kepada petugas lokal, bahkan ada pula yang terpaksa membayar zakat dua kali (Karim, 2001:192).

Dalam suasana yang penuh dengan pemberontakan dan Abu Bakar menginginkan legitimasi sebagai khalifah baru pengganti Rasulullah Saw, bahkan “delik hukum” yang awalnya berupa penolakan pembayaran zakat dapat digeser berdasarkan kepentingan stabilitas politik ke arah pembangkangan kepada ketentuan pemerintah pusat. Ketegasan khalifah Abu Bakar adalah respon atas kepekaan diri seorang pemimpin untuk memantapkan stabilitas negara dari segala gangguan yang tidak boleh ditoleransi karena akan merambat kepada gangguan lainnya (Ahmad, 2011:197). Sehingga wajar jika mereka diperangi dan menjadi satu paket bersama-sama dengan keputusan untuk memerangi orang yang secara terang-terangan keluar 
dari Islam. Karena sesaat setelah khalifah Abu Bakar mampu menyelesaikan peperangan dengan mereka dan keadaan politik kembali stabil, Umar ibn Khattab mengakui bahwa keputusan Abu Bakar untuk memerangi mereka adalah keputusan yang benar (Haekal, 2002) dan para imam madzhab pun menerima dan mengakui apa yang telah dilakukan oleh khalifah Abu Bakar pada saat itu dengan memberikan catatan bahwa kebijakan memerangi penentang zakat jika mereka berada di luar kendali pemerintahan, bukan karena mereka tidak tahu hukum zakat atau di bawah kendali pemerintahan (Ahmad, 2011:198).

Apa yang berbeda dari sikap yang diperlihatkan oleh khalifah Abu Bakar dan khalifah Umar ibn Khattab ketika bersikap kepada orang-orang yang enggan untuk mengeluarkan zakat? Dalam analisis Haekal (2002), Abu Bakar dan Umar memiliki cara pandang yang berbeda dalam melihat perilaku Rasulullah. Menurutnya, Abu Bakar hanya seorang pengikut sedangkan umar adalah seorang pembaru. Abu Bakar akan melanjutkan apa yang sudah dilakukan oleh Rasulullah. Beliau tidak akan peduli dengan apa yang terjadi di sekitarnya, apakah orang-orang setuju ataupun tidak, bahkan jika orang-orang itu melakukan pemberontakan. Sikap ini juga yang diperlihatkan oleh Abu Bakar kepada orang yang enggan untuk mengeluarkan zakat.

Perilaku untuk memerangi orang yang enggan untuk mengeluarkan zakat pernah akan dilakukan oleh Rasulullah. Turunnya surat al-Hujurat/49:6 menggambarkan tentang kesalahpahaman yang terjadi karena orang-orang yang mengeluarkan zakat dan hendak mengirimkan zakat ke Madinah diduga tidak akan mengeluarkan zakat, sehingga Rasulullah Saw pada saat itu bersiap untuk memerangi mereka (al-Qadli, 2007).

Mereka yang enggan untuk mengeluarkan zakat pada masa khalifah Abu Bakar adalah mereka yang memang berniat untuk tidak taat kepada khalifah. Mereka yang enggan adalah: (1) para pengikut para nabi palsu pada saat itu, Musailamah, Sajah Tulayhah, dan pengikut Aswad al-Ansi; (2) kaum Banu Kalb, Tayy, Duyban, dan lainnya meskipun mereka bukan pengikut para nabi palsu; (3) mereka yang bersikap menunggu perkembangan setelah wafatnya Rasulullah Saw, yaitu antara lain kaum Sulaim, Hawazin, dan Amir (Karim, 2001:192).

Jika analisis Haekal di atas tentang Abu Bakar dapat dibenarkan, maka analisis di atas sekaligus dapat digunakan untuk menemukan sistem apa saja yang digunakan oleh Abu Bakar dalam mengelola dan mendistribusikan dana zakat. Berarti sistem sentralisasi ataupun 


\section{Distribusi zakat di Indonesia: ...(Aden Rosadi dan Mohamad Anton Athoillah)}

desentralisasi bukanlah sistem yang ditetapkan oleh Islam, tetapi sistem yang dipilih karena keadaan tertentu sesuai tujuan yang hendak dicapai. Perang sudah terjadi pada masa Rasulullah dan terus terjadi pada masa khalifah Abu Bakar. Dana yang dihimpun telah digunakan dalam perang pada masa Rasulullah, tetapi di saat yang sama upaya untuk mendistribusikan dana kepada para mustahik lainnya juga dilakukan. Itulah yang dilakukan khalifah Abu Bakar sebagai pengikut dan penerus kepemimpinan Rasulullah Saw.

Sentralisasi adalah sistem yang dianut pada zaman jahiliyah yang hendak diperbarui (bukan dihilangkan) dengan datangnya Islam. Yusuf al-Qaradhawy (1991) dalam disertasinya mengkritik sistem yang dianut oleh masyarakat pada zaman jahiliyah (dan zaman kegelapan di benua eropa dan benua lainnya) itu dengan menghimpun banyak hadis bagaimana semangat Rasulullah untuk memaksimalkan desentralisasi bahwa zakat itu harus dibagikan ke daerah dimana zakat itu diambil. Ulama sepakat zakat fithrah dibagikan di tempat orang yang wajib mengeluarkan zakat fitrah tetapi mereka berbeda pendapat untuk zakat harta. Berarti semangat desentralisasi sudah sangat ditegaskan oleh Rasulullah. Dengan mengutip pendapat penulis al-Mughni, bahkan Yusuf al-Qardhawy (1991) menegaskan bahwa pemindahan zakat dari satu daerah ke daerah lain, dalam keadaan penduduknya membutuhkan adalah menodai hikmah zakat yang diwajibkan karenanya.

Ulama berbeda pendapat apakah boleh memindahkan dana zakat bila penduduk setempat masih membutuhkan dana itu. Empat ulama Islam sepakat untuk memberikan ketentuan yang ketat untuk dapat memindahkan dana zakat ke tempat yang lain. Kalangan Syafi'i berpendapat untuk tidak membolehkan memindahkan zakat dari satu daerah ke daerah lain, kecuali jika di daerah itu sudah tidak ada lagi mustahiknya. Kalangan Maliki mewajibkan zakat itu dibagikan di tempat di mana zakat itu didapat atau di daerah yang berdekatakan dengan daerah itu. Senada dengan kalangan Syafi'i, hanya boleh memindahkan jika di daerah itu sudah tidak ada lagi mustahiknya. Kalangan Hanafi menghukumi makruh untuk memindahkan zakat. Sementara kalangan Hanbali menilai orang yang memindahkan zakat itu telah berdosa (al-Qardhawy, 1991; al-Zuhaily, 1985).

Prioritas masalah yang akan diselesaikan dapat dijadikan pertimbangan untuk memilih apakah sentralisasi atau desentralisasi yang akan dipilih. Apa yang telah dilakukan oleh khalifah Abu Bakar pada saat itu dapat dijadikan pertimbangan tentang pentingnya sentralisasi dana 
zakat, karena dana itu akan digunakan untuk membiayai dan memobilisasi perang melawan orang-orang kafir. Tetapi jika yang menjadi prioritas adalah untuk mengentaskan kemiskinan, maka bentuk yang sama tidak dapat digunakan karena masalah kemiskinan lebih rumit dan ditentukan sesuai dengan faktor-faktor yang menjadi penyebabnya.

Sentralisasi distribusi dana zakat kepada golongan fakir-miskin tidak dapat dilakukan karena beberapa kelemahan, yaitu dihimpunnya dana zakat oleh pimpinan pusat tetapi seringkali rakyat miskin di daerah darimana dana zakat itu dihimpun tidak tersentuh sehingga masalah kemiskinan yang diderita mereka tidak terselesaikan. Masalah lain dari sentralisasi dana zakat untuk fakir-miskin adalah lemahnya pengawasan dan lambatnya distribusi zakat. Bahkan pada masa khalifah Utsman ibn Affan, upayanya untuk menjadikan dana zakat sebagai sumber pembiayaan perang justeru menuai banyak penolakan dari para sahabat karena dianggap menyalahi surat al-Taubah/9:60 dan mengakibatkan terganggunya sistem sirkulasi ekonomi, yang pada akhirnya menimbulkan kesulitan bagi pemerintahan itu sendiri (Perwataatmadja dan Byarwati, 2008:81).

Apa yang tidak bisa diabaikan dalam pendistribusian dana zakat adalah bertambahnya kuantitas, semakin rumitnya keadaan mustahik dan bertambahnya luas wilayah binaan/ kekuasaan. Sehingga meski khalifah Abu Bakar dan khalifah Utsman ibn Affan melakukan hal yang sama, yaitu menggunakan dana zakat untuk memobilisasi perang, tetapi mereka tidak mendapatkan tanggapan dan perlakuan yang sama dari para sahabat. Boleh jadi umat Islam pada masa khalifah Abu Bakar tidak sebanyak pada masa Utsman ibn Affan dan wilayah kekuasaan pada masa khalifah Abu Bakar belum seluas pada masa Utsman ibn Affan.

\section{Desentralisasi sebagai solusi distribusi di Indonesia}

Ada perbedaan yang cukup jelas antara sistem sentralisasi, desentralisasi dan atomisasi dalam pengelolaan dan pendistribusian dana zakat. Kebijakan zakat desentralistik adalah pengorganisasian zakat yang langsung berada dalam satu komando. Sebuah tingkatan kepemimpinan, baik di tingkat wilayah maupun daerah, mengoordinasi langsung seluruh keberadaan lembaga amil zakat yang ada di bawah naungan organisasi. Hal itu dilakukan untuk lebih memudahkan proses pengontrolan dan optimalisasi penghimpunan dan distribusi 


\section{Distribusi zakat di Indonesia: ...(Aden Rosadi dan Mohamad Anton Athoillah)}

dana zakat. Sedangkan kebijakan zakat "otonomisasi penuh" atau atomisasi adalah pemberian wewenang yang luas kepada semua tingkatan pimpinan untuk mengelola zakat (Latief, 2010:173).

Desentralisasi adalah solusi distribusi zakat yang dapat digunakan dalam upaya mencapai tujuan disyari'atkannya zakat. Fakta tentang luasnya wilayah dan tersebarnya kemiskinan di berbagai wilayah mengharuskan adanya upaya tertentu untuk sesegera menyelesaikan masalah kemiskinan secara merata di wilayah-wilayah yang tidak dapat dijangkau melalui sentralisasi zakat.

Semangat desentralisasi telah diperlihatkan, bahkan pada masa Rasulullah saw, Abu Bakar (w. 13 H/ 634 H), dan Umar ibn Khattab (w. 23 H/ 644 M). Pada masa itu, zakat diserahkan oleh pengumpul zakat untuk disimpan di bait al-mal apabila zakat yang telah dikumpulkan masih tersisa setelah dibagikan kepada para mustahik zakat yang berada di daerah pemungutan zakat (Ahmad, 2011:200). Pada masa khalifah Abu Bakar, bahkan bait al-mal tidak pernah menumpuk harta dalam jangka waktu yang lama karena langsung didistribusikan. Semua warga negara muslim mendapatkan bagian yang sama, dan ketika pendapatan bait al-mal meningkat, maka semua mendapat manfaat yang sama dan tidak ada yang hidup dalam kemiskinan (Perwataatmadja dan Byarwati, 2008:67-68).

Panduan tentang pendistribusiannya yang lebih menitikberatkan pada semangat desentralisasi ditemukan banyak dalam beberapa riwayat. Dana zakat yang terkumpul itu harus didistribusikan secara prioritatif, baik para mustahiknya atau pun wilayahnya, di tempat di mana dana zakat tersebut berhasil dikumpulkan (Abu 'Ubaid, 1976). Praktik desentralisasi ini harus diteladani oleh setiap pemimpin. Apabila petugas (distribusi) dana tidak mengetahui sehingga ia mendistribusikan dana itu ke tempat lain, padahal penduduknya asalnya membutuhkan, maka penguasa harus mengembalikan dana itu kepada mereka. Inilah yang dilakukan oleh Umar ibn Abdul Aziz (al-Qaradhawy, 1991). Mungkin inilah salah satu strategi yang pernah dilakukan, kenapa pada masa khalifah Umar ibn Abdul Aziz meski menjadi khalifah hanya sebentar tetapi mengalami zero-poverty.

Tercatat dalam informasi historis bahwa Badhan, salah seorang gubernur Kerajaan Persia untuk wilayah Yaman, pada saat itu, tetap memegang kekuasaan setelah ia menyatakan dirinya masuk Islam dan meninggalkan agama Majusi. Para gubernur yang lain, seperti di 
Bahrain, Hadramaut dan yang lain, dibiarkan dalam kekuasaan masing-masing setelah mereka beriman kepada Allah dan Rasul-Nya. Zakat yang dipungut dari sebagian penduduk daerah itu tetap dibagikan kepada orang-orang miskin di daerah itu juga (Haekal, $1354 \mathrm{H}$ ).

Analisis interpretatif bagi peristiwa ini dapat menggunakan konsep al-Ta'alluq al-Ma'nawi -Keterhubungan Maknawi - (Athoillah, 2006) atau konsep Munasabah dalam Hadis (Bazamul, 2014). Dengan konsep ini, sejumlah riwayat yang terkait dengan peristiwa tersebut, secara metodologis-konseptual, dihubungkan dengan sejumlah riwayat lain yang menginformasikan bagaimana kebijakan Nabi Muhammad Saw (w. 11 H/ 632 M), khalifah Umar ibn Khattab (w. $23 \mathrm{H} / 644 \mathrm{M}$ ), khalifah Ali ibn Abi Thalib (w. $40 \mathrm{H} / 661 \mathrm{M}$ ), para sahabat lain, para tabi'in sampai dengan masa khalifah Umar ibn Abd al-Aziz (w. 101 H/ 720 M), berkenaan dengan semangat desentralisasi zakat (Abu 'Ubaid, 1976).

Diperlukannya ketegasan distribusi (atau redistribusi) prioritatif dana zakat yang terkumpul, baik dari aspek personal para mustahiknya atau pun wilayah pendistribusiannya, tanpa melihat latar belakang keyakinan agama yang dianutnya, merupakan salah satu prinsip keadilan dalam ajaran Islam (Qaradhawy, 1991). Hal ini tentu saja menjadi sangat relevan dengan konteks negara bangsa (nation-state), termasuk Indonesia sebagai negara yang mayoritas penduduknya penganut Islam.

Semangat desentralisasi dalam pendistribusian dana zakat juga memiliki bibliografi-historis tersendiri. Ketika Nabi Muhammad Saw masih hidup, beliau mengangkat petugas khusus untuk mengumpulkan dan mendistribusikannya kembali di tempat di mana zakat tersebut dikumpulkan. Demikian juga dengan para sahabat Nabi. Umar ibn Khattab (w. 23 H/ 644 M) tercatat juga melakukan hal yang sama dengan yang dilakukan Nabi. Dalam sejumlah literatur, Mu'adz ibn Jabal (w. 18 H/ 639 M) adalah seorang sahabat yang terkenal sebagai petugas pengumpul zakat untuk wilayah Yaman, sejak masa Nabi sampai masa khalifah Umar ibn Khattab. Nabi memerintahkan Mu'adz untuk mndistribusikan dana zakat dari muzaki Yaman kepada mustahik Yaman. Pada masa pemerintahan khalifah Umar ibn Khattab, Mu'adz pernah membawa dana zakat dari Yaman ke pusat pemerintahan di Madinah. Akan tetapi khalifah Umar ibn Khattab menyuruhnya kembali ke Yaman untuk mendistribusikan dana zakat tersebut di wilayah Yaman. Informasi bibliografi-historis lain diketahui dari riwayat Farqad al-Sabakhi (w. 131 H/ 748 M), yang bertugas sebagai pengumpul 


\section{Distribusi zakat di Indonesia: ...(Aden Rosadi dan Mohamad Anton Athoillah)}

dana zakat. Ketika akan membagikannya di Makkah, Farqad bertemu dengan Sa’id ibn Jubair (w. 95 H/ 714 M). Setelah diketahuinya bahwa Farqad akan mendistribusikan dana zakat tersebut di Makkah, Sa'id melarangnya, untuk kemudian menyuruhnya kembali ke daerahnya dan membagikan dana zakat tersebut di daerahnya.

Kondisi tersebut, tanpa meniadakan kebolehan pendistribusian ke tempat lain, dalam pandangan Abu 'Ubaid (1976), dapat dipahami bahwa wilayah masyarakat dari kalangan mustahik, tempat di mana dana zakat tersebut dikumpulkan, lebih berhak menerima dana zakat yang dikumpulkan dari kalangan muzaki di antara mereka, sampai para mustahik tersebut tidak memerlukannya lagi. Keputuan boleh atau tidaknya pendistribusian dana zakat ke tempat lain, termasuk kas negara di pusat pemerintahan, merupakan tugas atau wewenang pemerintah. Secara historis-normatif, syarat utama kebolehan dana zakat didistribusikan ke tempat lain adalah apabila pada wilayah tempat di mana dana zakat dikumpulkan tersebut sudah terjadi Excess-Zakat (Demir, 2007) atau karena pertimbangan lain seperti keadaan masyarakat di tempat lain yang sudah tidak dapat diabaikan lagi (sangat darurat) sehingga pemimpin harus berijtihad untuk memindahkan dana zakat ke tempat itu, sebagaimana yang dianut oleh ulama kalangan Maliki (al-Qardhawy, 1991).

Berdasarkan informasi pustaka yang ada pula, dilaporkan bahwa karena komitmen dan konsistensi pemerintah dan para pejabat publiknya, Islam pernah berhasil mengentaskan kemiskinan pada masa khalifah Umar ibn Abdul Aziz (w.720 M/ 101 H). Dengan zakat sebagai salah satu instrumen pengentasannya, sejumlah wilayah dilaporkan telah mengalami zero-poverty (Ibn 'Abd al-Hakam, 1984). Pada masanya, sejarah mencatat semua warga masyarakat telah mampu menjadi muzakki. Warga menyalurkan dana filantropinya kepada masyarakat di Negara lain karena dikalangan umat Islam sangat sulit ditemukan kelompok yang berhak menerima dana zakat, infak ataupun sedekah (Gaus, 2008:11), meskipun masa pemerintahan (kekhilafahan)-nya hanya sebentar (Nadawy, 2000), atau hanya berlangsung 30 bulan (Perwataatmadja dan Byarwati, 2008:109).

Dari sudut pandang kekinian (keindonesiaan), ada keharusan kontinuitas pengentasan mustahik secara sistemik-komprehensif. Kebutuhan akan adanya perencanaan yang matang telah ditemukan kepastian landasan normatif-historisnya, program-program pengentasan mustahik secara khusus, atau kemiskinan secara umum, akan terus menemukan momentumnya, 
terutama yang berkaitan dengan zakat dan aspek-aspek religious-expenditure (pengeluaran yang bersifat keagamaan) lainnya. Dengan demikian, kontribusi agama (Islam) bagi pembangunan bangsa tetap signifikan sebagai perwujudan konsep Islam rahmatan li al'alamin (Athoillah, 2015).

Semangat desentralisasi dana zakat di Indonesia telah dilakukan. Ketentuan desentralisasi zakat didapat melalui UU No 23 Tahun 2011 Tentang Pengelolaan Zakat yang ditindaklanjuti dengan PP No 14 Tahun 2014 Tentang Pelaksanaan UU No 23 Tahun 2011 Tentang Pengelolaan Zakat. Berdasarkan UU No 23 Tahun 2013, zakat di Indonesia dikelola oleh BAZNAS, yaitu lembaga pemerintah pengelola zakat non-struktural yang bersifat mandiri dan bertanggung jawab kepada presiden melalui menteri. UU No 23 Tahun 2011 Pasal 15 mengatakan, dalam rangka pelaksanaan pengelolaan zakat pada tingkat provinsi dan kabupaten/kota dibentuk BAZNAS provinsi dan BAZNAS kabupaten/kota; Pasal 17 mengatakan, untuk membantu BAZNAS dalam pelaksanaan pengumpulan, pendistribusian, dan pendayagunaan zakat, masyarakat dapat membentuk LAZ; Pasal 25 mengatakan, zakat wajid didistribusikan kepada mustahik sesuai dengan syari'at Islam; Pasal 26 mengatakan, pendistribusian zakat dilakukan berdasarkan skala prioritas dengan memperhatikan prinsip pemerataan, keadilan, dan kewilayahan.

Sejak UU No 23 Tahun 1999 lahir, badan amil zakat tumbuh subur, baik badan amil yang didirikan oleh negara ataupun swasta. Dalam catatan (Widyawati, 2011:168), selain BAZNAS di tingkat nasional, ada 32 BAZ di tingkat provinsi dan 300 BAZ di tingkat kabupaten/kota. Kemudian 18 LAZ di tingkat nasional dan 70 LAZ yang berada di tingkat provinsi dan tingkat kabupaten/kota.

Masalah yang dihadapi di Indonesia khususnya, adalah tingkat kepercayaan masyarakat kepada lembaga amil zakat, baik lembaga yang didirikan oleh negara ataupun lembaga swasta. Dari data yang didapat oleh Ichsan Iqbal (2011:1-2), potensi yang mungkin didapat dari zakat sebesar Rp. 19,3 triliun (Rp. 6,2 triliun dari zakat fithrah dan Rp. 13,1 triliun dari zakat harta) diberikan tidak melalui lembaga. 92,8\% dari zakat harta diberikan langsung kepada penerima. Penerima terbesar adalah masjid-masjid sebesar 59\%, Badan Amil Zakat (BAZ) hanya 6\%, dan Lembaga Amil Zakat (LAZ) Swasta hanya 1,2\%. 


\section{Distribusi zakat di Indonesia: ...(Aden Rosadi dan Mohamad Anton Athoillah)}

Data lain didapat dari penelitian Imron Hadi Tamin (2011), zakat petani jeruk di di wilayah Sukoreno tidak diberikan kepada lembaga zakat tertentu tetapi lebih bersifat interpersonal, berbeda dengan zakat fithrah yang dikoordinasi oleh BAZIS masjid setempat. Zakat di wilayah Sukoreno diberikan kepada dua pihak, yaitu kepada orang-orang miskin secara langsung dan kepada masjid untuk dikelola dan distribusikan kembali kepada orangorang yang berhak untuk menerimanya. Alasan diberikannya zakat kepada orang-orang miskin karena mereka tahu siapa yang berhak untuk menerima zakat dan dapat dikatakan $100 \%$ distribusinya sampai kepada yang berhak.

\section{Penutup}

Islam tidak menentukan satu sistem tertentu terkait pengelolaan dan pendistribusian dana zakat. Uraian di atas membuktikan, bahwa baik sentralisasi ataupun desentralisasi pernah dilakukan oleh para khalifah Islam. Dipilihnya sentralisasi ataupun desentralisasi dipengaruhi di antaranya berdasarkan prioritas masalah yang hendak diselesaikan. Khalifah Abu Bakar pernah melakukan sentralisasi dana zakat seperti untuk membiayai dan memobilisasi perang untuk mempertahankan eksistensi agama (fi sabilillah). Pada masanya juga, beliau pernah melakukan desentralisasi distribusi dana zakat kepada golongan mustahik lainnya sebagai upaya tercapainya tujuan disyari'atkan zakat.

Dari sudut pandang keindonesiaan, desentralisasi menjadi pilihan terbaik dari setiap pilihan yang ada. Indonesia memiliki potensi yang sangat besar dari dana zakat yang dapat dikumpulkan. Dana itu idealnya didistribusikan ke tempat dimana dana itu dihimpun, kecuali di tempat itu sudah terjadi Excess-Zakat. Inilah yang dihadapi oleh badan amil zakat daerah atau lembaga amil zakat. Dengan berbagai program yang dimilikinya, program-program itu terkadang tidak menyentuh daerah dimana data itu dihimpun, sehingga masyarakat lebih tertarik untuk mendistribusikan dana zakat secara langsung kepada mustahik di daerahnya, atau mereka membentuk lembaga amil zakat setingkat rukun tetangga atau rukun warga kemudian mendistribusikan dana itu kepada mustahik di daerahnya.

Dari tabel dan data potensi zakat yang didapat oleh Ichsan Iqbal di atas, yang tidak didapat adalah data sekitar basis wilayah didapatnya dana zakat dan tujuan wilayah didistribusikannya dana zakat. Berdasarkan tabel dan data di atas, distribusi prioritatif berbasis 
golongan para mustahik telah dilakukan tetapi berbasis wilayah golongan mustahik belum dapat ditelusuri. Karena data di atas, apa yang direkomendasikan dalam tulisan ini adalah upaya penelitian lanjutan tentang distribusi dana zakat, tidak hanya berbasis golongan mustahik tetapi juga berbasis wilayah dan tujuan wilayah distribusi zakat. Ini sebagai upaya untuk mendukung atau membantah praktik desentralisasi sebagai praktik pengelolaan dan distribusi dana zakat yang paling baik di antara pilihan yang ada.

\section{Daftar pustaka}

'Abd al-Baqy, Al-Mu'jam Al-Mufahrash li Alfăş̧ al-Qur'an. Kairo: Dār al- Kutub al-'Ilmiyyah, $1364 \mathrm{H}$.

Abdullah, Muhammad dan Abdul Quddus Suhaib. The Impact of Zakat on Social Life of Muslim Society. Pakistan Journal of Islamic Research, Vol 8, 2011:85-91.

Abu 'Ubaid, Al-Amwāl. Beirut: Dār al-Shuruq, 1976 M/ 1409 H.

Ahmad, Ahmad Faiz. Ijtihad Abu Bakar Ash-Shidiq. Jakarta: Pustaka Balqis, 2011.

Al-Bukhari, Muhammad. Al-jami’ al-Ṣihahih. Riyadh: Bait al-Afkar al-Dawliyah, 1998 M/ $1419 \mathrm{H}$.

Al-Kasani. Bada’ al-Shana’. Beirut: Dar al-Kutub al-'Ilmiyyah, 2003.

Al-Nadawi, Abu Al-Hasan 'Ali Al-Hasani. Rijäl al-Fiker wa al-Da'wat fi al-Islam, diedit oleh Mushthafa Abu Sulaiman Al-Nadawy. Makkah al-Mukarramah: Maktabah Nizar Mushthafa al-Baz, $2000 \mathrm{M} / 1420 \mathrm{H}$.

Al-Qadli, Abd-Fattah Abd-Ghani. Asbāb al-Nuzūl 'an al-Shahab wa al-Mufassirin. Kairo: Dar al-Salam, 2007.

Al-Qaradhawy, Yusuf. Fiqh al-Zakah. Beirut: Muassasah al-Risalah, 1991.

Al-Suyuthi, Jalal Al-Din. Al-Itqān fi 'Ulum al-Qur'àn. Al-Madīnah Al-Munawwarah: Mujamma' Malik Fahd, $1426 \mathrm{H}$.

Al-Zuhaily, Wahbah. Al-Figh al-Islämi wa Adillatuh. Beirut: Dār al-Fikr, 1985.

Amalia, Euis. Keadilan Distributif dalam Islam. Jakarta: Rajawali Press, 2009.

An-Na'im, Abdullahi Ahmed. Islam and the Secular State: Negotiating the Future of Sharia. London: Harvard University Press, 2008.

Athoillah, Mohamad Anton. Ekonomi Zakat. Bandung: Pustaka Aura Semesta, 2015.

Athoillah, Mohamad Anton. Perbedaan Abl Al-Bait dan Al-Sunnab: Studi Hadits tentang Wasiat Nabi Saw. Bandung: Gunung Djati Press, 2006.

Baidhawy, Zakiyuddin. Distributive Principles of Economic Justice: an Islamic Perspective. 


\section{Distribusi zakat di Indonesia: ...(Aden Rosadi dan Mohamad Anton Athoillah)}

IJIMS, Indonesian Journal of Islam and Muslim Societies, Volume 2, Number 2, December 2012:241-266.

Bazamul, Muhammad bin 'Umar bin Salim. Tlmu Syarh al-Hadits wa Rawafid al-Babts cih, dalam https://uqu.edu.sa/files2/tinymce/plugins/filemanager/files/ 4052784/ filesave1/shrh. pdf (diunduh 22 Oktober 2014).

Demir, The Zakat Handbook: A Practical Guide for Muslims in the West. The Zakat Foundation of America, 2007.

Gaus, Ahmad dan Ahmad Gaus AF. Filantropi dalam Masyarakat Islam. Jakarta: Elex Media Komputindo, 2008.

Haekal, Muhammad Husain. Hayat Muhammad. Kairo: Dar al-Kutub al-Mishriyyah, 1354 H.

Haekal, Muhammad Husain. Umaribn Khattab. Diterjemahkan oleh Ali Audah. Bogor: Pustaka Litera Antar Nusa, 2002.

Hafidhuddin, Didin. Zakat dalam Perekonomian Modern. Jakarta: Gema Insani, 2002.

Hitti, Philip K. History of the Arabs. London: Macmillan and Co., 1946.

Ibn 'Abd al-Hakam, Abu Muhammad 'Abd al-Lah. Sirah Umar ibn Abd al-Ariz' 'ala mà Rawah al-Imam Malik ibn Anas wa Ashhabuh. Beirut: Ālam Al-Kitab, 1984 M/ 1404 H.

Ibn Manshur, Abdullah. Nawazil al-Zakah Dirasah Fiqhiyah Limustajaddat al-Zakah. Riyadl: Dar al-Maiman, $2008 \mathrm{M} / 1429 \mathrm{H}$.

Iqbal, Ichsan. Arsitektur Siklus Sistem Manajemen Strategi Pada Lembaga Amil Zakat Nasional Dompet Dhuafa. Disertasi Sekolah Pascasarjana UIN Syarif Hidayatullah Jakarta, 2011.

Karim, Adhiwarman A. Ekonomi Islam Suatu Kajian Kontemporer. Jakarta: Gema Insani, 2001.

Kasim, Muslim. Karakteristik Kemiskinan di Indonesia dan Strategi Penanggulangannya. Jakarta: Indomedia, 2006.

Khoiruddin, Heri. Tafsir Bisnis. Bandung: Fajar Media, 2014.

Latief, Hilman. Melayani Umat Filantropi Islam dan Ideologi Kesejabteraan Kaum Modernis. Jakarta: Gramedia, 2010.

Mas’udi, Masdar Farid. Pajak itu Zakat. Bandung: Mizan, 2010.

Muslim, Abu al-Husain Muslim ibn al-Hajjaj Muslim al-Nisaburi. Al-Jami' al-Shahih. Riyadl: Dar al-Mughni, $1998 \mathrm{M} / 1419 \mathrm{H}$.

Quthub, Sayyid. Fi Zhiläl al-Qur'an. Beirut: Dār al-Shuruq, 1968.

Ridha, Rasyid. Tafsir al-Qur'an al-Hakim. Kairo: Dar al-Manar, 1947M/ 1366 H.

Rejekiningsih, Tri Wahyu. Identifikasi Faktor Penyebab Kemiskinan di Kota Semarang dari Dimensi Kultural. Jurnal Ekonomi Pembangunan, Volume 12, Nomor 1, Juni 2011:2844. 
ljthad, Jurnal Wacana Hukum Islam dan Kemanusiaan, Volume 15, No. 2, Desember 2015: 237-256

Sasono, Adi dkk. Solusi Islam atas Problematika Umat. Jakarta: Gema Insani Press, 1998.

Tamin, Imron Hadi. "Peran Filantropi dalam Pengentasan Kemiskinan di dalam Komunitas Lokal", Jurnal Sosiologi Islam, Vol. 1 No. 1, April 2011: 35-58.

Vaglieri, Laura Veccia. "The Patriarchal and Umayyad Caliphates" in The Cambridge History Of Islam. Volume Ia The Central Islamic Lands From Pre-Islamic Times To The First World War, Edited By P. M. Holt, Ann K. S. Lambton, and Bernard Lewis. Cambridge: Cambridge University Press, 2008.

Wensinck, A. J., et. al. Al-Mu'jam al-Mufahrash li Alfäzh al-Hadits al-Nabany al-Syarif. Leiden: Maktabat Brill, 1936.

Widyawati. Filantropi Islam dan Kebijakan Negara Pasca Orde-Baru: Studi tentang Undang-undang Zakat dan Undang-undang Wakaf. Disertasi Sekolah Pascasarjana UIN Syarif Hidayatullah Jakarta, 2011. 